\title{
51- İlahiyat Fakültesi Arapça hazırlık sınıfı öğrencilerinin Arapça dersine ilişkin tutumlarının incelenmesi (Bursa Uludağ Üniversitesi, İlahiyat Fakültesi Örneği) ${ }^{12}$
}

\section{Ahmet İhsan DÜNDAR3}

APA: Dündar, A. İ. (2021). İlahiyat Fakültesi Arapça hazırlık sınıfı öğrencilerinin Arapça dersine ilişkin tutumlarının incelenmesi (Bursa Uludağ Üniversitesi, İlahiyat Fakültesi Örneği). RumeliDE Dil ve Edebiyat Araştırmaları Dergisi, (25), 844-868. DOI: 10.2900o/rumelide.1037512.

Öz

Bu çalışmada Bursa Uludağ Üniversitesi (BUÜ) İlahiyat Fakültesinde Arapça öğrenimi gören hazırlık sınıfı öğrencilerinin aldıkları derslere karşı geliştirdikleri tutumun çeşitli değişkenler doğrultusunda incelenmesi hedeflenmektedir. Bu inceleme çalışmamızın evreni, BUÜ İlahiyat Fakültesinde 2020 2021 eğitim öğretim yılında Arapça hazırlık sınıfında okuyan 432 öğrenciden oluşmaktadır. Örneklem grubunu ise belirtilen dönemde Arapça hazırlık eğitimi alan öğrencilerden çalışmaya katılan 166 öğrenci oluşmaktadır. Öğrencilerden veri toplanması için tarafımızdan oluşturulan "Kişisel Bilgi Formu” ile Uçar'ın (2013) geliştirdiği “Arapça Dersine Karşı Tutum Ölçeği” kullanılmıştır. Kişisel bilgi formunda öğrenim görülen program, yaş, cinsiyet, daha önce mezun olunan okul türü, uyruk, ebeveyn eğitim durumu, Arapça özel ders alıp almama, Kur'an hafizlığ durumu, ilahiyat fakültesi tercihi konusundaki isteklilik şeklinde bağımsız değişkenlere yer verilmiştir. Covid-19 pandemi koşulları nedeniyle anket çalışması çevrimiçi olarak uygulanmıştır. Çalışmanın soncunda Bursa Uludağ Üniversitesi İlahiyat Fakültesinde Arapça hazırlık sınıfı okuyan öğrencilerin aldıkları dersleri konusunda olumlu tutuma sahip oldukları görülmüştür. Özyeterlilik, motivasyon, ilgi, mesleki alana yönelik gereklilik, beklenti, kaygı ve gereklilik ve önem olarak yedi farklı alt grup üzerinden incelemede bulunulmuştur. Bağımsız grupların söz konusu alt gruplara göre incelenmesiyle anlamlı farklılık içeren sonuçlar elde edilmiş alt grupların bulunduğu görülmüştür. Arapça öğretiminin hali hazırdaki durumuna dair bilgi vermesi, geliştirilmesi ve ilerisi için yol göstermesi bakımından doğrudan sahadan alınan verilerle yürütülen bu tür çalışmaların sahanın uzmanları ve ilgilileri açısından fayda sağlayacağı değerlendirilmektedir.

Anahtar kelimeler: İlahiyat Fakültesi, hazırlık sınıfı, dil, Arapça, tutum, tutum ölçeği

Bu makale, Bursa Uludağ Üniversitesi BAP birimince desteklenmiş olan "İlahiyat Fakültesi Arapça Hazırlık Sinıfı Öğrencilerinin Arapça Dersine İlişkin Tutumlarının İncelenmesi (Bursa Uludağ Üniversitesi, İlahiyat Fakültesi Örneği)" adlı araştırma projesinden (2021-493) üretilmiştir. BUÜ Sosyal ve Beşeri Bilimler Araştırma ve Yayın Etik Kurulu tarafindan 29 Nisan 2021 tarihinde yapılan 2021-04 saylı oturumda alınan 47 numaralı karardaki onaya istinaden anket çalışması uygulanmıştır.

2 Bursa Uludağ Üniversitesi Araştırma ve Yayın Etik Kurulunun 47 numaralı yazısı ile araştırma için gerekli olan etik kurul izni alınmıştır.

Öğr. Gör. Dr., Bursa Uludağ Üniversitesi, İlahiyat Fakültesi, Temel İslam Bilimleri, Arap dili ve belagati (Bursa, Türkiye), ahmedundar@gmail.com, ORCID ID: 0ooo-0002-4178-2294 [Araştırma makalesi, Makale kayıt tarihi: 09.11.2021-kabul tarihi: 20.12.2021; DOI: 10.2900o/rumelide.1037512] 


\title{
Examination of Attitudes of Theology faculty Arabic preparatory class students towards Arabic lessons (The Case of The Faculty of Theology, Bursa Uludag University)
}

\begin{abstract}
Bursa Uludağ University (BUÜ) can be developed against the educated in the education-related to Arabic education. The universe of this research study consists of those who study in Arabic preparatory classes at BUU Faculty of Theology in the 2020-2021 academic year. For the data from the students, the "Person" to be created by us and the "Attitude Scale Towards Arabic Lesson" of Uçar (2013) were used. More programs than a personal knowledge, training program, age, educational background before target education, Arabic is tutoring program, nationality, education. The Covid19 pandemic was not classified as our study. A total of 166 floors have been built in the area grown in the area where it is located, in the entire grown school, and in the second school. As a result of Bursa Uludağ University, they have a positive attitude about receiving an education in university education. Self-efficacy, motivation, interest, professional requirement, expectation, anxiety, and importance were examined over different subgroups. Considering the independent subgroups in question, it is seen that there are sub-estimates with very high results. When the present article on English education is considered from the point of view of information, preparation and progress, it is useful for those who are interested in this type of field without being received from the field.
\end{abstract}

Keywords: Theology Faculty, preparatory class, language, Arabic, attitude, attitude scale

\section{Giriş}

Dil insan için en önemli iletişim aracıdır. En geniş tanımlamasına göre iletişim aracı olarak kabul edilen dilin (Üçok, 2004, s. 13), yaşayan bir varlığa benzetilmesi mümkündür. Dil denildiğinde öncelikle insanın diğer bir insanla olan iletişim aracı akla gelmekle birlikte insan ile doğa, insan ile makine ve artık günümüzde sözü edilen makine ile makine arası iletişim de dilin farklı türleri ve şekilleri yoluyla sağlanmaktadır. Yeni yerler ve nesneler keşfetme merakı, gerek tarım ve hayvancılığa, gerekse sanayi ve teknolojiye dayalı olarak yaşamını sürdürmek amacıyla farklı mekânlara intikal etme ihtiyacı, bununla bağlantılı olarak yeni pazarlar ve hammadde bulma isteği, bilgi ve deneyim paylaşımı, çeşitli alanlarda yürütülen ortak çalışmalar, yeni ideolojiler, fikir akımları, dinler ve inançlar insanoğlunun kendi ana dili dışındaki dilleri öğrenmesini zorunlu kılabilmektedir (Pan \& Akay, 2015). Maddi ya da manevi çeşitli ihtiyaçları karşılamak veya hedefleri gerçekleştirmek üzere öğrenme gayreti gösterilen dillerden birinin de Arapça olduğu görülmektedir.

Birleşmiş Milletler Teşkilatı'nın 18 Aralık 1973 tarihli ve 2206 numaralı genel oturumunda Arapça, Teşkilat komisyonlarının çalışma dili olarak kabul edilmiştir. Söz konusu kabul Arapçanın evrensel diller arasında yer aldığını göstermektedir (Civelek, 1998). Dünya çapında bir dil olmasıyla birlikte tarihi çok eskilere dayanan Arapça, din, tarih, kültür, ekonomi, siyaset, fikir, edebiyat, müzik alanlarında ve ayrıca askeri açıdan da büyük öneme sahiptir (Soysaldı, 2010, s. 248). İslam dininin temel kaynakları olan Kur'an-ı Kerim'in ve Hz. Peygamber'in dilinin Arapça olması, halkı Müslüman olan ülkelerde Arap diline önem verilmesinin ve öğrenilme çabasının en güçlü sebeplerinden biri olarak değerlendirilebilir.

Kur'an-ı Kerim'in, Hz. Peygamber'in söz ve eylemlerini içeren hadis-i şeriflerin ve diğer İslami kaynakların Arapça olması ve Müslüman toplumların asırlardan bu yana edebiyat, tarih, coğrafya, 
felsefe, mantık, matematik, fizik, tıp, astronomi, musiki gibi çeşitli ilim dallarında Arap diliyle kaleme alınmış binlerce eser vererek bir kültür ve medeniyet oluşturması, bu dilin öğrenilmesi ve öğretilmesini gerektiren başlıca sebeplerden sayılabilir. Bunun yanı sıra ülkemizdeki ve İslam dünyasındaki arşivlerde mevcut bulunan birçok vesikanın, yazma ve matbu çok sayıdaki eserin Arapça olması, geçmişte olduğu gibi günümüzde de bu dilin öğrenilme ve öğretilmesi gereğinin devam ettiğini göstermektedir (Civelek, 1998; Soysaldı, 2010). Zira geleceğe sağlam ve emin adımlarla yürüyebilmek için geçmişin iyi analiz edilmesi gerçeği önümüzde durmaktadır.

Ülkemizde Arapça öğretiminin geçmişi, Osmanlı dönemi ve hatta daha öncesi de hesaba katıldığında yüzyllara dayanmaktadır. Cumhuriyet döneminde resmi okullarda Arapça öğretimine bir süre ara verilmiş, daha sonra yapılan birtakım düzenlemelerin ardından çeşitli eğitim kademelerinde öğretim Arapça öğretim faaliyetleri yeniden başlamıştır (Civelek, 1998; Dündar, 2020, ss. 88-89; Soyupek, 2004).

$\mathrm{Bu}$ araştırmanın konusunu oluşturan İlahiyat Fakültelerinde Arapça hazırlık sınıfı uygulaması 1972 yılından 1997 yllına kadar devam etmiş ve YÖK tarafından alınan bir kararla Arapça hazırlık sınıfı öğretimine son verilmiştir. 2009-2010 eğitim öğretim yllından itibaren bazı üniversiteler bünyesinde yeniden başlatılmış olup 2013-2014 öğretim yllından itibaren ise birkaçı dışında bütün İlahiyat Fakültelerinde Arapça hazırlı programı zorunlu hale getirilmiştir (Arpaçukuru \& Üzümcü, 2020, s. 859; Özcan \& Yapıcı, 2016, s. 117). Arapça hazırlık sınıfı eğitiminin zorunlu olduğu üniversitelerden biri de Bursa Uludağ Üniversitesidir (BUÜ). Resmi Gazetede yayınlanan yönetmeliğe göre BUÜ Arapça hazırlık sınıfları eğitimi Yabancı Diller Yüksekokuluna bağlı olarak yürütülmektedir4.

İlgili yönetmeliğe göre hazırlık sınıfı öğrencilerine haftada en az 20 en fazla 30 saat olmak üzere Arapça dersi verilmekte olup hazırlık sınıfı eğitim-öğretiminin amacı şu şekilde ifade edilmiştir: "Avrupa Ortak Dil Çerçeve Kriterlerinde öngörülen, yabancı dilin temel kuralları ile sözlü ve yazılı anlama-anlatma yöntemlerini öğretmek, çeşitli alanlardaki yayınları izleyebilme becerisi edindirmek, sosyal ve akademik yaşam için gereken dil iletişimini sağlama yeterliğini kazandırmaktır”. BUÜ İlahiyat Fakültesinde örgün ve ikinci öğretim olarak uygulanan ikili öğretim, Arapça hazırlık sınıfları için de uygulanmaktadır.

\section{Yabancı dil olarak Arapça öğrenmede tutum}

Yabancı dil öğretiminin çok eskilere uzanan bir tarihçesi bulunmaktadır. Bu uzun geçmişin birikimi yanında yabancı dil öğretiminin ağırlığı daha da artmış durumdadır. Bunun nedenlerinden biri karmaşık iletişim ağı içinde evrenin adeta küçülmüş olmasıdır (Kocaman, 1983, s. 116). Yabancı dilin öğretimi konusunda yöntem önem arz etmektedir. Çok sayıda yöntem önerilmesine karşın gerçek anlamda ideal bir yöntemin bulunamamış olduğu da bir gerçektir. Zira dil öğretimine, yöntem dışında yönetici, öğretmen, öğrenci ve öğretim ortamı gibi unsurlar da girmektedir (Ekmekçi, 1983, ss. 107-108).

Dil öğretimine dâhil olan unsurlar içinde öğrenci unsurunun, yabancı dil öğrenme sürecinin sonucunda istenen düzeye gelmesinin veya başarılı sayılmasının özellikle iki faktör tarafından etkilendiği düşünülmektedir. Bunlardan birincisi tutum; ikincisi yabancı dil kaygısıdır. Olumlu tutum dil öğrenim sürecinin olumlu seyir izlemesini sağlarken olumsuz tutumların sonucunda kaygı ortaya çıkabilmekte ve bu da yabancı dil öğrenmeyi olumsuz etkilemektedir. Yabancı dil kaygısı bireyin kendisiyle ilgili

\footnotetext{
4 Bursa Uludağ Üniversitesi Yabancı Diller Yüksekokulu Yabancı Dil Eğitim-Öğretim ve Sınav Yönetmeliği. Resmi Gazete 31222 (23 Ağustos 2020). Erișim 6 Kasım 2021.

Bursa Uludă̆ Üniversitesi Yabancı Diller Yüksekokulu Yabancı Dil Eğitim-Öğretim ve Sınav Yönetmeliği. Resmi Gazete 31222 (23 Ağustos 2020). Erişim 6 Kasım 2021.
} 
olumsuz algıları, inançları ve davranışları gibi dil öğrenmeyi olumsuz etkileyecek çeşitli etkenlerle yakından ilgilidir (Pan \& Akay, 2015, s. 80).

Öğrencilerin bir dersle ilgili duyuşsal özelliklerinin en önemli göstergelerinden biri olan tutum, bireyin bir psikolojik objeye yönelik olumlu ya da olumsuz genel duygularıdır.(Arpacı, 2014, s. 79) Başka bir deyişle tutum, bir bireye atfedilen ve onun bir psikolojik obje ile ilgili düşünce, duygu ve davranışlarını düzenli bir biçimde oluşturan bir eğilimdir (Kömürcü, 2015, s. 124). Tutum, belirli nesne, durum, kurum, kavram ya da diğer insanlara karşı öğrenilmiş, olumlu ya da olumsuz tepkide bulunma eğilimi olarak da tanımlanmaktadır (Aydoslu, 2005, ss. 15-17; Tezbaşaran, 2008). Olumlu tutum sergileyen ve motive olmuş bir öğrenci dil öğrenimi konusunda harekete geçmekte ve bu hareketi sürdürmek için göstereceği çabanın muhtaç olduğu güç ve enerjiyi kendisinde bulabilmektedir (Özcan \& Geçioğlu, 2021, s. 390).

Yabancı dil öğrenen öğrencinin öğretim elemanına, genel planda dil öğrenimine, özel planda öğrendiği yabancı dile, o dili konuşan toplumsal gruba yönelik tutumu, dili öğrenme amacı vb. o yabancı dili öğrenmesini etkilemektedir. Hatta öğrencinin ailesinin o dile ve dili konuşan topluluğa karşı olumlu veya olumsuz tutumu da öğrenme sürecini etkileyebilmektedir. Olumlu tutuma sahip öğrencilerin o dili öğrenme istekleri artmakta ve bunun doğal sonucu olarak da öğrenme işlemi kolaylaşmaktadır (Ekmekçi, 1983, ss. 109-110).

İlahiyat fakültelerinde hazırlık sınıflarında yürütülmekte olan Arapça öğretim faaliyetlerinin hem kendi öz denetimini sağlaması ve başarısını arttırması bakımından hem de öğrencilerin başarısına katkı sunma imkânlarına ışık tutması açısından öğrencilerin yukarıda işaret edilen tutumları üzerine inceleme yapılması önem arz etmektedir. Bu kapsamda Arapça hazırlık sınıfı eğitimi alan öğrencilerin tutumlarını incelemek üzere çeşitli üniversitelerde çalışmalar yapılmıştır. Ancak böyle bir çalışmanın BUÜ Arapça hazırlık sınıfı öğrencileri üzerinde yapılmadığı tespit edilmiştir. Literatüre katkı sağlanması, daha sonraki meta analizler için materyal oluşturulması ve nihai olarak Arapça hazırlık eğitiminin daha da iyileştirilmesi hedeflenerek böyle bir çalışmanın yararlı olacağı düşünülmüştür.

\section{Araştırmanın amacı}

Bu çalışmada 2020-2021 eğitim öğretim döneminde Uludağ Üniversitesi İlahiyat Fakültesinde öğrenim görmeye hak kazanmış olup zorunlu Arapça dil dersi almakta olan öğrencilerin, derslere yönelik tutumlarının çeşitli değişkenler bakımından incelenmesi amaçlanmaktadır.

$\mathrm{Bu}$ amaca yönelik olarak şu alt problemlere cevap aranmıştır:

1. Bursa Uludă̆ Üniversitesinde Arapça hazırlık öğrenimi gören öğrencilerin Arapça dersleri konusunda bağımsız değişkenlerle bağımlı değişkenler arasında anlamlı bir ilişki bulunmakta mıdır?

2. $\quad$ İlahiyat Fakültesi’nden önce mezun oldukları okul türü, öğrencilerin Arapça hazırlık sınıfı derslerine yönelik tutumlarını etkilemekte midir?

3. Öğrencilerin cinsiyetleri ile Arapça hazırlık sınıfı derslerine ilişkin tutum arasında anlamlı bir ilişki var mıdır?

4. Ö̈̆grenim gördükleri birinci öğretim veya ikinci öğretim programı ile öğrencilerin Arapça hazırlık sınıfı derslerine yönelik tutum arasında anlamlı bir ilişki bulunmakta mıdır? 
5. $\quad$ Yaş grupları ile Arapça hazırlık sınıfı derslerine ilişkin tutum arasında anlamlı bir ilişki var midır?

6. $\quad$ Öğrencilerin uyrukları ile Arapça hazırlık sınıfı derslerine ilişkin tutum arasında anlamlı bir ilişki var mıdır?

7. Annelerinin eğitim durumuyla öğrencilerin Arapça hazırlık sınıfı derslerine ilişkin tutum arasında anlamlı bir ilişki var mıdır?

8. Babalarının eğitim durumuyla öğrencilerin Arapça hazırlık sınıfı derslerine ilişkin tutum arasında anlamlı bir ilişki var mıdır?

9. Daha önceden Arapça özel ders alınıp alınmamasıyla Arapça hazırlık sınıfı derslerine ilişkin tutum arasında anlamlı bir ilişki var mıdır?

10. İlahiyat Fakültesi’nde okumaya istekli olup olmama ile Arapça hazırlık sınıfı derslerine ilişkin tutum arasında anlamlı bir ilişki var mıdır?

11. Kur'an-ı Kerim hafızlığı yapıp yapmama ile Arapça hazırlık sınıfı derslerine ilişkin tutum arasında anlamlı bir ilişki var mıdır?

12. Arapça çalışmak için haftalık olarak ayırdıkları süre ile Arapça hazırlık sınıfı derslerine ilişkin tutum arasında anlamlı bir ilişki bulunmakta mıdır?

\section{Araştırmanın Yöntemi}

İlahiyat fakültesi Arapça hazırlık sınıfı programında öğrenim gören öğrencilerin bu sınıfta aldıkları derslere yönelik tutumlarının belirlenmesini amaçlayan bu çalışmada nicel araştırma yöntemleri kullanılmıştır. Uçar tarafından geliştirilen "İlahiyat Fakültelerinde Okutulan Arapça Dersine Karşı Tutum Ölçeği Geliştirme Çalışması” (Uçar, 2015) ölçek uygulanmıştır.

Bireylerin bir objeye yönelik olarak tutumlarının tespit edilmesi, söz konusu objeye yönelik olarak bir tutum ölçeğinin geliştirilmesine ve uygulanmasına bağlı bulunmaktadır. Günümüzde artık tek boyutlu ölçeklemeden başlayarak, çok boyutlu ölçmelere kadar çeşitli ve daha karmaşı işlemlere dayalı teknikler bulunmaktadır. Bu tekniklerden en yaygın olarak kullanılanı dereceleme toplamıyla ölçekleme modeli olarak da bilinmekte olan likert tipi ölçeklerdir (Genç, 2013; Tezbaşaran, 2008; Turan vd., 2015). Bir toplamalı sıralama tekniği olan likert ölçeği, tutum ölçekleri içerisinde en yaygın olarak kullanılanıdır. Bunun sebebi, likert tipi ölçeklerin geliştirilmesinin diğer ölçeklere göre daha kolay ve kullanışlılığının da yüksek olmasıdır. Likert yönteminde ifadeler, obje ile doğrudan doğruya ilişkilerine bakılarak hazırlanmayıp, bunun yerine işe yarama derecelerine bakılarak konu ile ilişkisi olan hususlar dikkate alınarak dolaylı bir şekilde hazırlanmaktadır (Tavşancıl, 2005).

\section{a. Veri Toplama aracı}

Veri toplama aracı olarak yukarıda belirtilen tutum ölçeği kullanılmıştır. Ölçeğin bütün olarak Cronbach Alpha güvenirlik katsayısı o,872 olarak hesaplanmıştır. Ölçeğin birinci faktörünün (Özyeterlilik) Cronbach Alpha değeri 0,748, ikinci faktörünki (Motivasyon) 0,785, üçüncü faktörünki (İlgi) 0,725, dördüncü faktörünki (Mesleki Alana Yönelik Gereklilik) o,763, beşinci faktörünki (Beklenti) o,777, 
altıncı faktörünki (Kaygı) o,812 ve yedinci faktörünki ise (Gereklilik ve Önem) o,805 olarak hesaplanmıştır. Güvenirlik analizinde Alpha değerinin en az 0.70 olması gerektiği (Anderson, 1988; Kline, 1994; Peers, 1996) göz önünde bulundurulduğunda, ölçeğin tümünün yanı sıra her bir alt boyutunun da oldukça güvenilir bir düzeyde olduğu ifade edilebilir. Bunun yanında, öğrencilerin ölçeklerden aldıkları puanlar ile ölçeklerin faktörleri arasında pozitif ve doğrusal bir ilişkinin olduğu tespit edilmiştir. Buradan hareketle, ölçeğin tüm faktörleri arasında bir tutarllığın olduğu söylenebilir. Yapılan açımlayıcı faktör analizleri sonucunda elde edilen değerler itibari ile geliştirilen ölçeğin geçerli ve güvenilir bir ölçek olduğu belirtilebilir (Uçar, 2015, ss. 134-139).

\section{b. Verilerin analizi}

Anket verilerinin analizinde SPSS 20.0 (Statistical Package fort he Social Sciences) bilgisayar programından yararlanılmıştır. Anketlerden elde edilen verilerin çözümlenmesinde frekans, yüzde ve $\mathrm{X}^{2}$ (Key Kare) tekniklerinden yararlanılmıştır. Araştırma verilerinin analizinde elde edilen verilere göre frekans dağılımlarıyla ilgili analiz yapılarak standart sapma aritmetik ortalaması değerlendirilmiştir. Yine veri türüne göre korelasyon "t” testi ve "tek yönlü varyans analizi (One- way ANOVA)" yapılmıştır. "F" değerinin anlamlı olması durumunda farkın hangi gruplardan kaynaklandığını bulmak için "Tukey" uygulanmıştır. İstatiksel analizlerde de 0,5 anlamlılık düzeyi esas alınmıştır (Tavşancıl, 2005).

\section{Araştırmadan elde edilen bulgular}

\section{Demografik bilgilerin dağılımı}

Katılımcılara ait demografik bilgilerin n ve \% değerleri:

Tablo 1: Demografik Bilgilerin Dağılımı

\begin{tabular}{|c|c|c|c|}
\hline & & $\mathrm{n}$ & $\%$ \\
\hline \multirow{3}{*}{ Öğretim programınız nedir? } & Örgün öğretim & 99 & 59,6 \\
\hline & İkinci öğretim & 67 & 40,4 \\
\hline & Total & 166 & 100,0 \\
\hline \multirow{3}{*}{ Cinsiyetiniz nedir? } & Erkek & 65 & 39,2 \\
\hline & Kadın & 101 & 60,8 \\
\hline & Total & 166 & 100,0 \\
\hline \multirow{3}{*}{ Yaş } & $18-24$ & 158 & 95,2 \\
\hline & $25-31$ & 8 & 4,8 \\
\hline & Total & 166 & 100,0 \\
\hline \multirow{5}{*}{$\begin{array}{l}\text { Daha önce mezun olduğunuz okul türü } \\
\text { nedir? }\end{array}$} & İmam Hatip Lisesi & 114 & 68,7 \\
\hline & Diğer Lise & 38 & 22,9 \\
\hline & İlahiyat Ön Lisans & 11 & 6,6 \\
\hline & Lisans & 3 & 1,8 \\
\hline & Total & 166 & 100,0 \\
\hline \multirow{3}{*}{ Uyruk } & Türk & 154 & 92,8 \\
\hline & Yabancı & 12 & 7,2 \\
\hline & Total & 166 & 100,0 \\
\hline
\end{tabular}




\begin{tabular}{|l|l|l|l|}
\hline \multirow{5}{*}{ Anne eğitim durumu } & Okuma yazma bilmiyor & 17 & 10,2 \\
\cline { 2 - 4 } & Illkokul & 96 & 57,8 \\
\cline { 2 - 4 } & Ortaokul/Lise & 48 & 28,9 \\
\cline { 2 - 4 } & Ön lisans & 2 & 1,2 \\
\cline { 2 - 4 } & Üniversite & 3 & 1,8 \\
\hline & Total & 166 & 100,0 \\
\hline \multirow{5}{*}{ Baba eğitim durumu } & Okuma yazma bilmiyor & 4 & 2,4 \\
\cline { 2 - 4 } & İlkokul & 53 & 31,9 \\
\cline { 2 - 4 } & Ortaokul/Lise & 76 & 45,8 \\
\cline { 2 - 4 } & Ön lisans & 13 & 7,8 \\
\cline { 2 - 4 } & Üniversite & 16 & 9,6 \\
\cline { 2 - 4 } & Yüksek Lisans/Doktora & 4 & 2,4 \\
\cline { 2 - 4 } & Total & 166 & 100,0 \\
\hline
\end{tabular}

Öğretim programının türüne göre dağılım incelendiğinde; örgün öğretimde olanların oranı \%59,6, ikinci öğretimde olanların oranı \%40,4’tür. Cinsiyete göre dağılım incelendiğinde erkeklerin oranı \%39,2, kadınların oranı \%60,8'dir. Yaş gruplarına göre dağılım incelendiğinde 18-24 yaş grubu kişilerin oranı $\% 95,2$ olup 25 ve daha büyük olanların oranı \%4,8'dir. Daha önce mezun olunan okul türü dağılımı incelendiğinde imam hatip lisesi mezunları oranı \%68,7, diğer lise türlerinden mezun olanların oranı \%22,9, ilahiyat ön lisans mezunu olanların oranı \%6,6 olup lisans mezunu olanların oranı \%1,8’tir. Katılımcıların \%92,8'i Türk, \%7,2'si ise yabancı uyrukludur. Annesi okuma yazma bilmeyenlerin oranı $\% 10,2$, ilkokul mezunu olanların oranı \%57,8, ortaokul/lise mezunu olanların oranı \%28,9, ön lisans mezunu olanların oranı \%1,2 olup üniversite mezunu olanların oranı \%1,8'dir. Baba eğitim durumuna göre dağılım incelendiğinde babası okuma yazma bilmeyenlerin oranı \%2,4, ilkokul mezunu olanların oranı \%31,9, ortaokul/lise mezunu olanların oranı \%45,8, ön lisans mezunu olanların oranı \%7,8 olup üniversite mezunu olanların oranı \%9,6, yüksek lisans/doktora mezunu olanların oranı \%2,4'tür.

Tablo-2: Demografik Bilgilerin Dağılımı-2

\begin{tabular}{|c|c|c|c|}
\hline & & $\mathrm{n}$ & $\%$ \\
\hline \multirow{3}{*}{ Arapça özel ders alma durumu } & Evet & 19 & 11,4 \\
\hline & Hayır & 147 & 88,6 \\
\hline & Total & 166 & 100,0 \\
\hline \multirow{3}{*}{$\begin{array}{l}\text { İlahiyat fakültesine istekli olarak mi } \\
\text { geldiniz? }\end{array}$} & Evet & 144 & 86,7 \\
\hline & Hayır & 22 & 13,3 \\
\hline & Total & 166 & 100,0 \\
\hline \multirow{3}{*}{ Kur'an-ı Kerim hafizlığı yaptınız mı? } & Evet & 15 & 9,0 \\
\hline & Hayır & 151 & 91,0 \\
\hline & Total & 166 & 100,0 \\
\hline \multirow{4}{*}{$\begin{array}{l}\text { Arapça derslerine çalışmak için bir haftada } \\
\text { ne kadar zaman ayıryorsunuz? }\end{array}$} & Hiç & 7 & 4,2 \\
\hline & $<1$ saat & 10 & 6,0 \\
\hline & 1-2 saat & 27 & 16,3 \\
\hline & 3-4 saat & 34 & 20,5 \\
\hline
\end{tabular}




\begin{tabular}{|l|l|l|l|}
\hline \multirow{2}{*}{} & $5-6$ saat & 27 & 16,3 \\
\cline { 2 - 4 } & $7-8$ saat & 19 & 11,4 \\
\cline { 2 - 4 } & 8 saatten fazla & 42 & 25,3 \\
\cline { 2 - 4 } & Total & 166 & 100,0 \\
\hline
\end{tabular}

Arapça özel ders alanların oranı \%11,4 olup ilahiyat fakültesine istekli olarak gelenlerin oranı \%86,7'dir. Kuran-ı kerim hafızlı̆̆ yapanların oranı \%9 olup yapmayanların oranı \%91'dir. Arapça derslerine çalışmak için haftada ayrılan zaman incelendiğinde hiç zaman ayırmayanların oranı \%4,2, 1 saatten az zaman ayıranların oranı \%6, 1-2 saat zaman ayıranların oranı \%16,3, 3-4 saat süre ayıranların oranı \%20,5, 5-6 saat ayıranların oranı \%16,3 olup 7-8 saat ayıranların oranı \%11,4 olup 8 saatten fazla vakit ayrranların oranı \%25,3’tür.

\section{Arapça dersine karşı tutum ölçeğinin öğretim türüne göre değişimi}

Arapça dersine karşı tutum ölçeğinin öğrenim türüne göre ortalamaları ve bu ortalamalar arasındaki farkın anlamlı olup olmadığının tespiti için yapılan bağımsız gruplarda t testi sonuçları verilmiştir.

Tablo-3: Öğretim Türüne Göre Değişim

\begin{tabular}{|c|c|c|c|c|c|c|}
\hline & & $\mathrm{n}$ & Ortalama & $\begin{array}{l}\text { Std. } \\
\text { Sapma }\end{array}$ & $\mathrm{t}$ & $\mathrm{p}$ \\
\hline \multirow[t]{3}{*}{ Toplam } & Örgün öğretim & 99 & 3,32 & 0,29 & \multirow{3}{*}{0,792} & \multirow{3}{*}{0,375} \\
\hline & İkinci öğretim & 67 & 3,36 & 0,34 & & \\
\hline & Total & 166 & 3,34 & 0,31 & & \\
\hline \multirow[t]{3}{*}{ Özyeterlilik } & Örgün öğretim & 99 & 3,23 & 0,56 & \multirow{3}{*}{1,852} & \multirow{3}{*}{0,175} \\
\hline & İkinci öğretim & 67 & 3,35 & 0,56 & & \\
\hline & Total & 166 & 3,28 & 0,56 & & \\
\hline \multirow[t]{3}{*}{ Motivasyon } & Örgün öğretim & 99 & 3,33 & 0,43 & \multirow{3}{*}{0,044} & \multirow{3}{*}{0,834} \\
\hline & İkinci öğretim & 67 & 3,35 & 0,50 & & \\
\hline & Total & 166 & 3,34 & 0,46 & & \\
\hline \multirow[t]{3}{*}{ İlgi } & Örgün öğretim & 99 & 3,49 & 0,50 & \multirow{3}{*}{0,198} & \multirow{3}{*}{0,657} \\
\hline & İkinci öğretim & 67 & 3,45 & 0,51 & & \\
\hline & Total & 166 & 3,47 & 0,50 & & \\
\hline \multirow{3}{*}{$\begin{array}{l}\text { Mesleki Alana } \\
\text { Yönelik } \\
\text { Gereklilik }\end{array}$} & Örgün öğretim & 99 & 3,12 & 0,43 & \multirow{3}{*}{0,898} & \multirow{3}{*}{0,345} \\
\hline & İkinci öğretim & 67 & 3,19 & 0,56 & & \\
\hline & Total & 166 & 3,15 & 0,49 & & \\
\hline \multirow[t]{3}{*}{ Beklenti } & Örgün öğretim & 99 & 3,13 & 0,38 & \multirow{3}{*}{1,313} & \multirow{3}{*}{0,253} \\
\hline & İkinci öğretim & 67 & 3,21 & 0,51 & & \\
\hline & Total & 166 & 3,16 & 0,44 & & \\
\hline \multirow[t]{4}{*}{ Kaygı } & Örgün öğretim & 99 & 3,51 & 0,68 & \multirow{3}{*}{0,144} & \multirow{3}{*}{0,705} \\
\hline & İkinci öğretim & 67 & 3,55 & 0,69 & & \\
\hline & Total & 166 & 3,52 & 0,69 & & \\
\hline & Örgün öğretim & 99 & 4,05 & 1,00 & 0,955 & 0,330 \\
\hline
\end{tabular}



of Theology, Bursa Uludag University) / A. İ. Dündar (pp. 844-868)

Gereklilik ve Önem

$$
\begin{array}{|l|}
\text { İkinci öğretim } \\
\hline \text { Total }
\end{array}
$$

$\mid$\begin{tabular}{l|}
67 \\
166
\end{tabular}

\begin{tabular}{|l|l|}
3,89 & 1,05 \\
\hline 3,98 & 1,02
\end{tabular}

Arapça dersine karşı tutum ölçeğinin öğretim türüne göre dağılımı incelendiğinde ölçek geneli ile alt boyutlarının hiç birisinin öğretim türüne göre anlamlı düzeyde farklılık göstermediği görülmüştür (p>0,05). Diğer bir ifade ile örgün öğretim ve ikinci öğretim öğrencilerinin Arapça dersine karşı genel tutum düzeyi ve alt boyutları düzeyleri aynı seviyededir.

\section{Arapça dersine karşı tutum ölçeğinin cinsiyete göre değişimi}

Arapça dersine karşı tutum ölçeğinin cinsiyete göre ortalamaları ve bu ortalamalar arasındaki farkın anlamlı olup olmadığının tespiti için yapılan bağımsız gruplarda t testi sonuçları verilmiştir.

Tablo-4: Cinsiyete Göre Değişim

\begin{tabular}{|c|c|c|c|c|c|c|}
\hline & & $\mathrm{n}$ & Ortalama & Std. Sapma & $\mathrm{t}$ & $\mathrm{p}$ \\
\hline \multirow[t]{3}{*}{ Toplam } & Erkek & 65 & 3,28 & 0,38 & \multirow{3}{*}{3,509} & \multirow{3}{*}{$0,043^{*}$} \\
\hline & Kadın & 101 & 3,37 & 0,25 & & \\
\hline & Total & 166 & 3,34 & 0,31 & & \\
\hline \multirow[t]{3}{*}{ Özyeterlilik } & Erkek & 65 & 3,18 & 0,53 & \multirow{3}{*}{3,390} & \multirow{3}{*}{$0,047^{*}$} \\
\hline & Kadın & 101 & 3,34 & 0,57 & & \\
\hline & Total & 166 & 3,28 & 0,56 & & \\
\hline \multirow[t]{3}{*}{ Motivasyon } & Erkek & 65 & 3,30 & 0,53 & \multirow{3}{*}{0,875} & \multirow{3}{*}{0,351} \\
\hline & Kadın & 101 & 3,37 & 0,40 & & \\
\hline & Total & 166 & 3,34 & 0,46 & & \\
\hline \multirow[t]{3}{*}{ İlgi } & Erkek & 65 & 3,44 & 0,60 & \multirow{3}{*}{0,609} & \multirow{3}{*}{0,436} \\
\hline & Kadın & 101 & 3,50 & 0,43 & & \\
\hline & Total & 166 & 3,47 & 0,50 & & \\
\hline \multirow{3}{*}{$\begin{array}{l}\text { Mesleki Alana Yönelik } \\
\text { Gereklilik }\end{array}$} & Erkek & 65 & 3,16 & 0,51 & \multirow{3}{*}{0,042} & \multirow{3}{*}{0,838} \\
\hline & Kadın & 101 & 3,14 & 0,48 & & \\
\hline & Total & 166 & 3,15 & 0,49 & & \\
\hline \multirow[t]{3}{*}{ Beklenti } & Erkek & 65 & 3,19 & 0,49 & \multirow{3}{*}{0,414} & \multirow{3}{*}{0,521} \\
\hline & Kadın & 101 & 3,15 & 0,41 & & \\
\hline & Total & 166 & 3,16 & 0,44 & & \\
\hline \multirow[t]{3}{*}{ Kaygı } & Erkek & 65 & 3,38 & 0,76 & \multirow{3}{*}{4,981} & \multirow{3}{*}{$0,027^{*}$} \\
\hline & Kadın & 101 & 3,62 & 0,62 & & \\
\hline & Total & 166 & 3,52 & 0,69 & & \\
\hline \multirow[t]{3}{*}{ Gereklilik ve Önem } & Erkek & 65 & 3,74 & 1,18 & \multirow{3}{*}{6,309} & \multirow{3}{*}{$0,013^{*}$} \\
\hline & Kadın & 101 & 4,14 & 0,87 & & \\
\hline & Total & 166 & 3,98 & 1,02 & & \\
\hline
\end{tabular}

${ }^{*} \mathrm{p}<0,05$ 
Bağımsız gruplarda t testi sonuçlarına göre; Arapça dersine karşı tutum ölçeği toplamı ile öz yeterlilik, kaygı ve gereklilik ve önem alt boyutları cinsiyete göre anlamlı düzeyde farklılık göstermektedir $(\mathrm{p}<0,05)$. Kadınların Arapça dersine karşı tutum ölçeği toplamı ile öz yeterlilik, kaygı ve gereklilik ve önem alt boyutları erkeklerden anlamlı derecede daha yüksektir.

\section{Arapça dersine karşı tutum ölçeğinin yaşa göre değişimi}

Arapça dersine karşı tutum ölçeğinin yaşa göre ortalamaları ve bu ortalamalar arasındaki farkın anlamlı olup olmadığının tespiti için yapılan bağımsız gruplarda t testi sonuçları verilmiştir.

Tablo-5: Yaşa Göre Değişim

\begin{tabular}{|c|c|c|c|c|c|c|}
\hline & & $\mathrm{n}$ & Ortalama & Std. Sapma & $\mathrm{t}$ & $\mathrm{P}$ \\
\hline \multirow[t]{3}{*}{ Toplam } & $18-24$ & 158 & 3,34 & 0,31 & \multirow{3}{*}{0,245} & \multirow{3}{*}{0,622} \\
\hline & $25^{+}$ & 8 & 3,39 & 0,32 & & \\
\hline & Total & 166 & 3,34 & 0,31 & & \\
\hline \multirow[t]{3}{*}{ Özyeterlilik } & $18-24$ & 158 & 3,27 & 0,55 & \multirow{3}{*}{1,065} & \multirow{3}{*}{0,304} \\
\hline & $25^{+}$ & 8 & 3,48 & 0,74 & & \\
\hline & Total & 166 & 3,28 & 0,56 & & \\
\hline \multirow[t]{3}{*}{ Motivasyon } & $18-24$ & 158 & 3,33 & 0,45 & \multirow{3}{*}{1,018} & \multirow{3}{*}{0,315} \\
\hline & $25^{+}$ & 8 & 3,50 & 0,62 & & \\
\hline & Total & 166 & 3,34 & 0,46 & & \\
\hline \multirow[t]{3}{*}{ İlgi } & $18-24$ & 158 & 3,45 & 0,50 & \multirow{3}{*}{6,957} & \multirow{3}{*}{$0,009^{*}$} \\
\hline & $25^{+}$ & 8 & 3,92 & 0,22 & & \\
\hline & Total & 166 & 3,47 & 0,50 & & \\
\hline \multirow{3}{*}{$\begin{array}{l}\text { Mesleki Alana Yönelik } \\
\text { Gereklilik }\end{array}$} & $18-24$ & 158 & 3,15 & 0,48 & \multirow{3}{*}{0,017} & \multirow{3}{*}{0,896} \\
\hline & $25^{+}$ & 8 & 3,12 & 0,74 & & \\
\hline & Total & 166 & 3,15 & 0,49 & & \\
\hline \multirow[t]{3}{*}{ Beklenti } & $18-24$ & 158 & 3,17 & 0,44 & \multirow{3}{*}{1,157} & \multirow{3}{*}{0,284} \\
\hline & $25^{+}$ & 8 & 3,00 & 0,52 & & \\
\hline & Total & 166 & 3,16 & 0,44 & & \\
\hline \multirow[t]{3}{*}{ Kayg1 } & $18-24$ & 158 & 3,56 & 0,63 & \multirow{3}{*}{11,310} & \multirow{3}{*}{$0,001^{*}$} \\
\hline & $25^{+}$ & 8 & 2,75 & 1,21 & & \\
\hline & Total & 166 & 3,52 & 0,69 & & \\
\hline \multirow[t]{3}{*}{ Gereklilik ve Önem } & $18-24$ & 158 & 3,98 & 0,99 & \multirow{3}{*}{0,003} & \multirow{3}{*}{0,959} \\
\hline & $25^{+}$ & 8 & 4,00 & 1,58 & & \\
\hline & Total & 166 & 3,98 & 1,02 & & \\
\hline
\end{tabular}

${ }^{*} \mathrm{p}<0,05$

Bağımsız gruplarda t testi sonuçlarına göre; ilgi ve kaygı alt boyutları yaş gruplarına göre anlamlı düzeyde farklılık gösterirken ( $\mathrm{p}<0,05$ ), ölçeğin geneli ile diğer alt boyutlar yaş gruplarına göre anlamlı düzeyde farklılık göstermektedir ( $\mathrm{p}<0,05) .25+$ yaş grubunun ilgi boyutu 18-24 yaş grubundan anlamlı 
düzeyde daha yüksek iken, 18-24 yaş grubunun kaygı düzeyi 25+ yaş grubundan anlamlı derecede daha yüksektir.

\section{Arapça dersine karşı tutum ölçeğinin daha önce mezun olunan okul türüne göre değişimi}

Arapça dersine karşı tutum ölçeğinin yaşa göre ortalamaları ve bu ortalamalar arasındaki farkın anlamlı olup olmadığının tespiti için yapılan tek yönlü varyans analizi sonuçları verilmiştir.

Tablo-6: Mezun Olunan Okul Türüne Göre Değişim

\begin{tabular}{|c|c|c|c|c|c|c|}
\hline & & $n$ & Ortalama & $\begin{array}{l}\text { Std. } \\
\text { Sapma }\end{array}$ & $\mathrm{F}$ & $\mathrm{p}$ \\
\hline \multirow[t]{5}{*}{ Toplam } & İmam Hatip Lisesi & 114 & 3,33 & 0,34 & \multirow{5}{*}{0,175} & \multirow{5}{*}{0,913} \\
\hline & Diğer Lise & 38 & 3,33 & 0,23 & & \\
\hline & İlahiyat Ön Lisans & 11 & 3,40 & 0,31 & & \\
\hline & Lisans & 3 & 3,39 & 0,26 & & \\
\hline & Total & 166 & 3,34 & 0,31 & & \\
\hline \multirow[t]{5}{*}{ Özyeterlilik } & İmam Hatip Lisesi & 114 & 3,26 & 0,56 & \multirow{5}{*}{0,240} & \multirow{5}{*}{0,868} \\
\hline & Diğer Lise & 38 & 3,29 & 0,54 & & \\
\hline & İlahiyat Ön Lisans & 11 & 3,41 & 0,64 & & \\
\hline & Lisans & 3 & 3,30 & 0,95 & & \\
\hline & Total & 166 & 3,28 & 0,56 & & \\
\hline \multirow[t]{5}{*}{ Motivasyon } & İmam Hatip Lisesi & 114 & 3,33 & 0,48 & \multirow{5}{*}{1,182} & \multirow{5}{*}{0,318} \\
\hline & Diğer Lise & 38 & 3,33 & 0,36 & & \\
\hline & İlahiyat Ön Lisans & 11 & 3,34 & 0,51 & & \\
\hline & Lisans & 3 & 3,83 & 0,25 & & \\
\hline & Total & 166 & 3,34 & 0,46 & & \\
\hline \multirow[t]{5}{*}{ İlgi } & İmam Hatip Lisesi & 114 & 3,42 & 0,53 & \multirow{5}{*}{4,036} & \multirow{5}{*}{$0,008^{*}$} \\
\hline & Diğer Lise & 38 & 3,48 & 0,41 & & \\
\hline & İlahiyat Ön Lisans & 11 & 3,85 & 0,27 & & \\
\hline & Lisans & 3 & 4,04 & 0,19 & & \\
\hline & Total & 166 & 3,47 & 0,50 & & \\
\hline \multirow{5}{*}{$\begin{array}{l}\text { Mesleki Alana } \\
\text { Yönelik Gereklilik }\end{array}$} & İmam Hatip Lisesi & 114 & 3,15 & 0,46 & \multirow{5}{*}{0,469} & \multirow{5}{*}{0,704} \\
\hline & Diğer Lise & 38 & 3,14 & 0,52 & & \\
\hline & İlahiyat Ön Lisans & 11 & 3,05 & 0,41 & & \\
\hline & Lisans & 3 & 3,43 & 1,24 & & \\
\hline & Total & 166 & 3,15 & 0,49 & & \\
\hline \multirow[t]{4}{*}{ Beklenti } & İmam Hatip Lisesi & 114 & 3,21 & 0,48 & \multirow{4}{*}{1,754} & \multirow{4}{*}{0,158} \\
\hline & Diğer Lise & 38 & 3,07 & 0,27 & & \\
\hline & İlahiyat Ön Lisans & 11 & 3,15 & 0,49 & & \\
\hline & Lisans & 3 & 2,76 & 0,30 & & \\
\hline
\end{tabular}




\begin{tabular}{|c|c|c|c|c|c|c|}
\hline & Total & 166 & 3,16 & 0,44 & & \\
\hline \multirow[t]{5}{*}{ Kayg1 } & İmam Hatip Lisesi & 114 & 3,58 & 0,63 & \multirow{5}{*}{5,314} & \multirow{5}{*}{$0,002 *$} \\
\hline & Diğer Lise & 38 & 3,54 & 0,63 & & \\
\hline & İlahiyat Ön Lisans & 11 & 3,25 & 0,98 & & \\
\hline & Lisans & 3 & 2,13 & 0,92 & & \\
\hline & Total & 166 & 3,52 & 0,69 & & \\
\hline \multirow{5}{*}{$\begin{array}{l}\text { Gereklilik ve } \\
\text { Önem }\end{array}$} & İmam Hatip Lisesi & 114 & 3,89 & 1,04 & \multirow{5}{*}{1,037} & \multirow{5}{*}{0,378} \\
\hline & Diğer Lise & 38 & 4,17 & 0,82 & & \\
\hline & İlahiyat Ön Lisans & 11 & 4,27 & 1,25 & & \\
\hline & Lisans & 3 & 3,83 & 1,61 & & \\
\hline & Total & 166 & 3,98 & 1,02 & & \\
\hline
\end{tabular}

${ }^{*} \mathrm{p}<0,05$

Tek yönlü varyans analizi sonuçlarına göre; Arapça dersine karşı tutum ölçeği alt boyutlarından ilgi ve kaygı alt boyutları daha önce mezun olunan lise türüne göre anlamlı düzeyde farklılı gösterirken ( $p<0,05)$, ölçeğin toplamı ve diğer alt boyutlar anlamlı farklllık göstermemektedir ( $>>0,05)$. Anlamlı farklılık gösteren alt boyutlar için farklılığın hangi gruptan kaynaklandığını tespit etmek için yapılan TUKEY testi sonuçlarına göre;

İlgi alt boyutu için; lisans bölümü mezunlarının ilgi düzeyi imam hatip lisesi, diğer lise ve ilahiyat ön lisans mezunlarından anlamlı derecede daha büyüktür. Ek olarak ilahiyat ön lisans mezunlarının ilgi düzeyi, imam hatip lisesi ve diğer lise mezunlarından anlamlı derecede daha büyüktür.

Kaygı alt boyutu için imam hatip lisesi ve diğer lise mezunlarının kaygı düzeyi diğer gruplardan anlamlı derecede daha yüksektir. Ek olarak ilahiyat ön lisans mezunlarının ortalaması lisans mezunlarından anlamlı derecede daha yüksektir.

\section{Arapça dersine karşı tutum ölçeğinin uyruğa göre değişimi}

Arapça dersine karşı tutum ölçeğinin uyruğa göre ortalamaları ve bu ortalamalar arasındaki farkın anlamlı olup olmadığının tespiti için yapılan bağımsız gruplarda t testi sonuçları verilmiştir.

Tablo-7: Uyruğa Göre Değişim

\begin{tabular}{|c|c|c|c|c|c|c|}
\hline & & $\mathrm{n}$ & Ortalama & Std. Sapma & $\mathrm{t}$ & $\mathrm{p}$ \\
\hline \multirow[t]{3}{*}{ Toplam } & Türk & 154 & 3,34 & 0,32 & \multirow{3}{*}{0,169} & \multirow{3}{*}{0,682} \\
\hline & Yabanc1 & 12 & 3,37 & 0,22 & & \\
\hline & Total & 166 & 3,34 & 0,31 & & \\
\hline \multirow[t]{3}{*}{ Özyeterlilik } & Türk & 154 & 3,28 & 0,56 & \multirow{3}{*}{0,074} & \multirow{3}{*}{0,785} \\
\hline & Yabancı & 12 & 3,24 & 0,52 & & \\
\hline & Total & 166 & 3,28 & 0,56 & & \\
\hline \multirow[t]{3}{*}{ Motivasyon } & Türk & 154 & 3,34 & 0,46 & \multirow{3}{*}{0,047} & \multirow{3}{*}{0,829} \\
\hline & Yabancı & 12 & 3,37 & 0,37 & & \\
\hline & Total & 166 & 3,34 & 0,46 & & \\
\hline
\end{tabular}




\begin{tabular}{|c|c|c|c|c|c|c|}
\hline \multirow[t]{3}{*}{ İlgi } & Türk & 154 & 3,47 & 0,50 & \multirow{3}{*}{0,015} & \multirow{3}{*}{0,903} \\
\hline & Yabancı & 12 & 3,49 & 0,52 & & \\
\hline & Total & 166 & 3,47 & 0,50 & & \\
\hline \multirow{3}{*}{$\begin{array}{l}\text { Mesleki Alana Yönelik } \\
\text { Gereklilik }\end{array}$} & Türk & 154 & 3,13 & 0,49 & \multirow{3}{*}{1,892} & \multirow{3}{*}{0,171} \\
\hline & Yabancı & 12 & 3,33 & 0,52 & & \\
\hline & Total & 166 & 3,15 & 0,49 & & \\
\hline \multirow[t]{3}{*}{ Beklenti } & Türk & 154 & 3,15 & 0,45 & \multirow{3}{*}{1,183} & \multirow{3}{*}{0,278} \\
\hline & Yabancı & 12 & 3,30 & 0,34 & & \\
\hline & Total & 166 & 3,16 & 0,44 & & \\
\hline \multirow[t]{3}{*}{ Kaygı } & Türk & 154 & 3,53 & 0,70 & \multirow{3}{*}{0,141} & \multirow{3}{*}{0,708} \\
\hline & Yabanc1 & 12 & 3,45 & 0,48 & & \\
\hline & Total & 166 & $3,5^{2}$ & 0,69 & & \\
\hline \multirow[t]{3}{*}{ Gereklilik ve Önem } & Türk & 154 & 3,98 & 1,04 & \multirow{3}{*}{0,004} & \multirow{3}{*}{0,949} \\
\hline & Yabancı & 12 & 4,00 & 0,71 & & \\
\hline & Total & 166 & 3,98 & 1,02 & & \\
\hline
\end{tabular}

Bağımsız gruplarda t testi sonuçlarına göre Arapça dersine karşı tutum ölçeği geneli ile alt boyutları uyruğa göre anlamlı düzeyde farklılık göstermemektedir (p>0,05). Diğer bir ifade ile Türk ve yabancı öğrencilerin Arapça dersine karşı tutum ölçeği toplamı ile alt boyutları aynı düzeydedir.

\section{Arapça dersine karşı tutum ölçeğinin anne eğitim durumuna göre değişimi}

Arapça dersine karşı tutum ölçeğinin anne eğitim durumuna göre ortalamaları ve bu ortalamalar arasındaki farkın anlamlı olup olmadığının tespiti için yapılan tek yönlü varyans analizi sonuçları verilmiştir.

Tablo-8: Anne Eğitim Durumuna Göre Değișim

\begin{tabular}{|c|c|c|c|c|c|c|}
\hline & & $\mathrm{n}$ & Ortalama & $\begin{array}{l}\text { Std. } \\
\text { Sapma }\end{array}$ & $\mathrm{F}$ & $\mathrm{p}$ \\
\hline \multirow[t]{6}{*}{ Toplam } & Okuma yazma bilmiyor & 17 & 3,26 & 0,28 & \multirow{6}{*}{0,675} & \multirow{6}{*}{0,610} \\
\hline & İlkokul & 96 & 3,37 & 0,23 & & \\
\hline & Ortaokul/Lise & 48 & 3,31 & 0,44 & & \\
\hline & Ön lisans & 2 & 3,38 & 0,05 & & \\
\hline & Üniversite & 3 & 3,33 & 0,15 & & \\
\hline & Total & 166 & 3,34 & 0,31 & & \\
\hline \multirow[t]{6}{*}{ Özyeterlilik } & Okuma yazma bilmiyor & 17 & 3,14 & 0,47 & \multirow{6}{*}{0,755} & \multirow{6}{*}{0,556} \\
\hline & İlkokul & 96 & 3,34 & 0,55 & & \\
\hline & Ortaokul/Lise & 48 & 3,21 & 0,64 & & \\
\hline & Ön lisans & 2 & 3,33 & 0,00 & & \\
\hline & Üniversite & 3 & 3,17 & 0,09 & & \\
\hline & Total & 166 & 3,28 & 0,56 & & \\
\hline Motivasyon & Okuma yazma bilmiyor & 17 & 3,24 & 0,46 & 0,316 & 0,867 \\
\hline
\end{tabular}




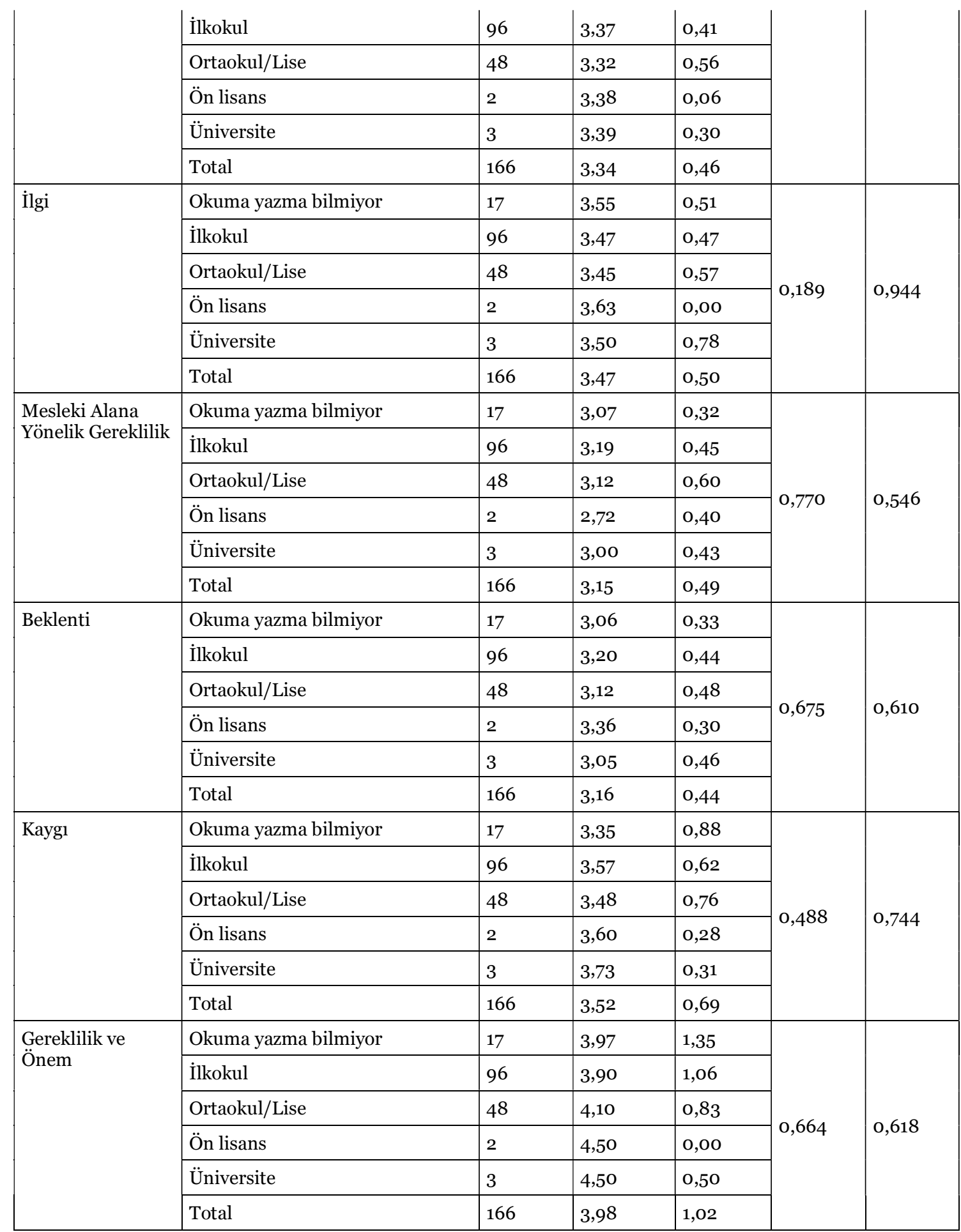

Tek yönlü varyans analizi sonuçlarına göre; Arapça dersine karşı tutum ölçeği geneli ile alt boyutları anne eğitim durumuna göre anlamlı düzeyde farklılı göstermemektedir (p>0,05). Diğer bir ifade ile annesi farklı eğitim seviyesine sahip kişilerin Arapça dersine karşı tutum düzeyleri aynı seviyededir denilebilir. 


\section{Arapça dersine karşı tutum ölçeğinin baba eğitim durumuna göre değişimi}

Arapça dersine karşı tutum ölçeğinin baba eğitim durumuna göre ortalamaları ve bu ortalamalar arasındaki farkın anlamlı olup olmadı̆̆ının tespiti için yapılan tek yönlü varyans analizi sonuçları verilmiştir.

Tablo-9: Baba Eğitim Durumuna Göre Değişim

\begin{tabular}{|c|c|c|c|c|c|c|}
\hline & & $\mathrm{n}$ & Ortalama & $\begin{array}{l}\text { Std. } \\
\text { Sapma }\end{array}$ & $\mathrm{F}$ & $\mathrm{p}$ \\
\hline \multirow[t]{7}{*}{ Toplam } & Okuma yazma bilmiyor & 4 & 3,35 & 0,12 & \multirow{7}{*}{0,530} & \multirow{7}{*}{0,753} \\
\hline & İlkokul & 53 & 3,38 & 0,26 & & \\
\hline & Ortaokul/Lise & 76 & 3,32 & 0,36 & & \\
\hline & Ön lisans & 13 & 3,38 & 0,22 & & \\
\hline & Üniversite & 16 & 3,28 & 0,33 & & \\
\hline & Yüksek Lisans/Doktora & 4 & 3,25 & 0,30 & & \\
\hline & Total & 166 & 3,34 & 0,31 & & \\
\hline \multirow[t]{7}{*}{ Özyeterlilik } & Okuma yazma bilmiyor & 4 & 3,17 & 0,52 & \multirow{7}{*}{0,590} & \multirow{7}{*}{0,707} \\
\hline & İlkokul & 53 & 3,31 & 0,59 & & \\
\hline & Ortaokul/Lise & 76 & 3,30 & 0,58 & & \\
\hline & Ön lisans & 13 & 3,17 & 0,44 & & \\
\hline & Üniversite & 16 & 3,30 & 0,50 & & \\
\hline & Yüksek Lisans/Doktora & 4 & 2,88 & 0,26 & & \\
\hline & Total & 166 & 3,28 & 0,56 & & \\
\hline \multirow[t]{7}{*}{ Motivasyon } & Okuma yazma bilmiyor & 4 & 3,31 & 0,45 & \multirow{7}{*}{0,901} & \multirow{7}{*}{0,482} \\
\hline & İlkokul & 53 & 3,40 & 0,43 & & \\
\hline & Ortaokul/Lise & 76 & 3,32 & 0,50 & & \\
\hline & Ön lisans & 13 & 3,46 & 0,28 & & \\
\hline & Üniversite & 16 & 3,17 & 0,41 & & \\
\hline & Yüksek Lisans/Doktora & 4 & 3,23 & 0,40 & & \\
\hline & Total & 166 & 3,34 & 0,46 & & \\
\hline \multirow[t]{7}{*}{ İlgi } & Okuma yazma bilmiyor & 4 & 3,60 & 0,48 & \multirow{7}{*}{0,676} & \multirow{7}{*}{0,642} \\
\hline & İlkokul & 53 & 3,40 & 0,46 & & \\
\hline & Ortaokul/Lise & 76 & 3,52 & 0,55 & & \\
\hline & Ön lisans & 13 & 3,59 & 0,41 & & \\
\hline & Üniversite & 16 & 3,38 & 0,52 & & \\
\hline & Yüksek Lisans/Doktora & 4 & 3,50 & 0,35 & & \\
\hline & Total & 166 & 3,47 & 0,50 & & \\
\hline \multirow{4}{*}{$\begin{array}{l}\text { Mesleki Alana } \\
\text { Yönelik Gereklilik }\end{array}$} & Okuma yazma bilmiyor & 4 & 3,36 & 0,38 & \multirow{4}{*}{1,069} & \multirow{4}{*}{0,380} \\
\hline & İlkokul & 53 & 3,23 & 0,51 & & \\
\hline & Ortaokul/Lise & 76 & 3,06 & 0,52 & & \\
\hline & Ön lisans & 13 & 3,20 & 0,38 & & \\
\hline
\end{tabular}




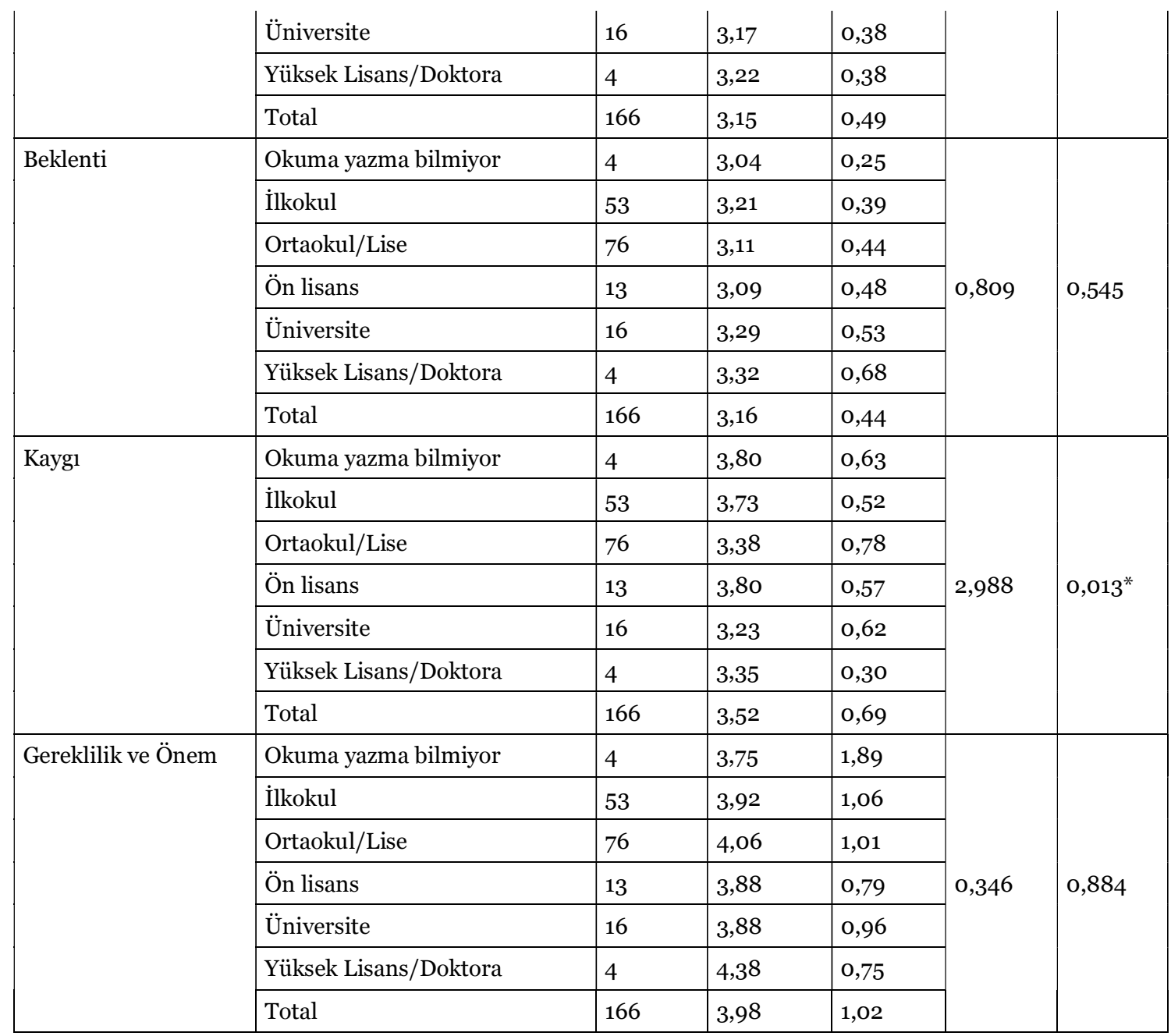

*p<0,05

Tek yönlü varyans analizi sonuçlarına göre; Arapça dersine karşı tutum ölçeği alt boyutlarından kaygı alt boyutu baba eğitim durumuna göre anlamlı düzeyde farklılık göstermektedir ( $\mathrm{p}<0,05)$. Farklılığın hangi gruptan kaynaklandı̆̆ını tespit etmek için yapılan TUKEY testi sonuçlarına göre; babası okuma yazma bilmeyen, ilkokul mezunu olan ve ön lisans mezunu olanların kaygı düzeyi babası ortaokul/lise, üniversite ve yüksek lisans/doktora mezunu olanların kaygı düzeyinden anlamlı derecede daha yüksektir.

\section{Arapça dersine karşı tutum ölçeğinin Arapça özel ders alma durumuna göre değişimi}

Arapça dersine karşı tutum ölçeğinin Arapça özel ders alma durumuna göre ortalamaları ve bu ortalamalar arasındaki farkın anlamlı olup olmadığının tespiti için yapılan bağımsız gruplarda t testi sonuçları verilmiştir. 
860 / RumeliDE Journal of Language and Literature Studies 2021.25 (December)

Examination of Attitudes of Theology faculty Arabic preparatory class students towards Arabic lessons (The Case of The Faculty of Theology, Bursa Uludag University) / A. İ. Dündar (pp. 844-868)

Tablo-10: Arapça Özel Ders Alma Durumuna Göre Değişim

\begin{tabular}{|c|c|c|c|c|c|c|}
\hline & & $\mathrm{n}$ & Ortalama & Std. Sapma & $\mathrm{t}$ & $\mathrm{p}$ \\
\hline \multirow[t]{3}{*}{ Toplam } & Evet & 19 & 3,34 & 0,15 & \multirow{3}{*}{0,001} & \multirow{3}{*}{0,977} \\
\hline & Hayır & 147 & 3,34 & 0,32 & & \\
\hline & Total & 166 & 3,34 & 0,31 & & \\
\hline \multirow[t]{3}{*}{ Özyeterlilik } & Evet & 19 & 3,25 & 0,37 & \multirow{3}{*}{0,041} & \multirow{3}{*}{0,840} \\
\hline & Hayır & 147 & 3,28 & 0,58 & & \\
\hline & Total & 166 & 3,28 & 0,56 & & \\
\hline \multirow[t]{3}{*}{ Motivasyon } & Evet & 19 & 3,32 & 0,35 & \multirow{3}{*}{0,060} & \multirow{3}{*}{0,806} \\
\hline & Hayır & 147 & 3,34 & 0,47 & & \\
\hline & Total & 166 & 3,34 & 0,46 & & \\
\hline \multirow[t]{3}{*}{ İlgi } & Evet & 19 & 3,44 & 0,46 & \multirow{3}{*}{0,086} & \multirow{3}{*}{0,769} \\
\hline & Hayır & 147 & 3,48 & 0,51 & & \\
\hline & Total & 166 & 3,47 & 0,50 & & \\
\hline \multirow{3}{*}{$\begin{array}{l}\text { Mesleki Alana Yönelik } \\
\text { Gereklilik }\end{array}$} & Evet & 19 & 3,15 & 0,47 & \multirow{3}{*}{0,002} & \multirow{3}{*}{0,962} \\
\hline & Hayır & 147 & 3,15 & 0,49 & & \\
\hline & Total & 166 & 3,15 & 0,49 & & \\
\hline \multirow[t]{3}{*}{ Beklenti } & Evet & 19 & 3,29 & 0,35 & \multirow{3}{*}{1,853} & \multirow{3}{*}{0,175} \\
\hline & Hayır & 147 & 3,15 & 0,45 & & \\
\hline & Total & 166 & 3,16 & 0,44 & & \\
\hline \multirow[t]{3}{*}{ Kayg1 } & Evet & 19 & 3,45 & 0,50 & \multirow{3}{*}{0,217} & \multirow{3}{*}{0,642} \\
\hline & Hayır & 147 & 3,53 & 0,71 & & \\
\hline & Total & 166 & 3,52 & 0,69 & & \\
\hline \multirow[t]{3}{*}{ Gereklilik ve Önem } & Evet & 19 & 4,16 & 0,82 & \multirow{3}{*}{0,640} & \multirow{3}{*}{0,425} \\
\hline & Hayır & 147 & 3,96 & 1,04 & & \\
\hline & Total & 166 & 3,98 & 1,02 & & \\
\hline
\end{tabular}

Bağımsız gruplarda t testi sonuçlarına göre; Arapça dersine karşı tutum ölçeğinin geneli ile alt boyutları Arapça özel ders alma durumuna göre anlamlı düzeyde farklılık göstermemektedir (p>0,05). Diğer bir ifade ile Arapça özel ders alan ve almayanların Arapça dersine karşı tutum ölçeği düzeyleri aynı seviyededir.

\section{Arapça dersine karşı tutum ölçeğinin İlahiyat Fakültesine isteyerek gelme durumuna göre değişimi}

Arapça dersine karşı tutum ölçeğinin ilahiyat fakültesine isteyerek gelme durumuna göre ortalamaları ve bu ortalamalar arasındaki farkın anlamlı olup olmadığının tespiti için yapılan bağımsız gruplarda t testi sonuçları verilmiştir. 
Tablo-11: İlahiyat Fakültesine İsteyerek Gelme Durumuna Göre Değişim

\begin{tabular}{|c|c|c|c|c|c|c|}
\hline & & $\mathrm{n}$ & Ortalama & Std. Sapma & $t$ & $\mathrm{p}$ \\
\hline \multirow[t]{3}{*}{ Toplam } & Evet & 144 & 3,35 & 0,31 & \multirow{3}{*}{0,484} & \multirow{3}{*}{0,488} \\
\hline & Hayır & 22 & 3,30 & 0,29 & & \\
\hline & Total & 166 & 3,34 & 0,31 & & \\
\hline \multirow[t]{3}{*}{ Özyeterlilik } & Evet & 144 & 3,27 & 0,58 & \multirow{3}{*}{0,152} & \multirow{3}{*}{0,697} \\
\hline & Hayır & 22 & 3,32 & 0,46 & & \\
\hline & Total & 166 & 3,28 & 0,56 & & \\
\hline \multirow[t]{3}{*}{ Motivasyon } & Evet & 144 & 3,35 & 0,46 & \multirow{3}{*}{1,030} & \multirow{3}{*}{0,312} \\
\hline & Hayır & 22 & 3,25 & 0,45 & & \\
\hline & Total & 166 & 3,34 & 0,46 & & \\
\hline \multirow[t]{3}{*}{ İlgi } & Evet & 144 & 3,51 & 0,50 & \multirow{3}{*}{4,897} & \multirow{3}{*}{$0,028^{*}$} \\
\hline & Hayır & 22 & 3,26 & 0,44 & & \\
\hline & Total & 166 & 3,47 & 0,50 & & \\
\hline \multirow{3}{*}{$\begin{array}{l}\text { Mesleki Alana Yönelik } \\
\text { Gereklilik }\end{array}$} & Evet & 144 & 3,12 & 0,49 & \multirow{3}{*}{2,509} & \multirow{3}{*}{0,115} \\
\hline & Hayır & 22 & 3,30 & 0,44 & & \\
\hline & Total & 166 & 3,15 & 0,49 & & \\
\hline \multirow[t]{3}{*}{ Beklenti } & Evet & 144 & 3,16 & 0,44 & \multirow{3}{*}{0,187} & \multirow{3}{*}{0,666} \\
\hline & Hayır & 22 & 3,20 & 0,46 & & \\
\hline & Total & 166 & 3,16 & 0,44 & & \\
\hline \multirow[t]{3}{*}{ Kayg1 } & Evet & 144 & 3,54 & 0,69 & \multirow{3}{*}{0,798} & \multirow{3}{*}{0,373} \\
\hline & Hayır & 22 & 3,40 & 0,69 & & \\
\hline & Total & 166 & 3,52 & 0,69 & & \\
\hline \multirow[t]{3}{*}{ Gereklilik ve Önem } & Evet & 144 & 4,03 & 1,02 & \multirow{3}{*}{2,958} & \multirow{3}{*}{0,087} \\
\hline & Hayır & 22 & 3,64 & 0,94 & & \\
\hline & Total & 166 & 3,98 & 1,02 & & \\
\hline
\end{tabular}

${ }^{*} \mathrm{p}<0,05$

Bağımsız gruplarda t testi sonuçlarına göre; Arapça dersine karşı tutum ölçeğinin ilgi alt boyutu ilahiyat fakültesine isteyerek gelme durumuna göre anlamlı düzeyde farklılı gösterirken $(\mathrm{p}<0,05)$, ölçeğin toplamı ve diğer alt boyutlar ilahiyat fakültesine isteyerek gelme durumuna göre anlamlı düzeyde farklılık göstermemektedir. İlahiyat fakültesine isteyerek gelenlerin ilgi düzeyi isteyerek gelmeyenlerden anlamlı derecede daha yüksektir.

\section{Arapça dersine karşı tutum ölçeğinin Kur’an-ı Kerim hafızlığı yapma durumuna göre değişimi}

Arapça dersine karşı tutum ölçeğinin Kur'an-ı Kerim Hafızlığı yapma durumuna göre ortalamaları ve bu ortalamalar arasındaki farkın anlamlı olup olmadığının tespiti için yapılan bağımsız gruplarda t testi sonuçları verilmiştir. 
862 / RumeliDE Journal of Language and Literature Studies 2021.25 (December)

Examination of Attitudes of Theology faculty Arabic preparatory class students towards Arabic lessons (The Case of The Faculty of Theology, Bursa Uludag University) / A. İ. Dündar (pp. 844-868)

Tablo-12: Kur’an-ı Kerim Hafizlığı Yapma Durumuna Göre Değişim

\begin{tabular}{|c|c|c|c|c|c|c|}
\hline & & $n$ & Ortalama & Std. Sapma & $\mathrm{t}$ & $\mathrm{p}$ \\
\hline \multirow[t]{3}{*}{ Toplam } & Evet & 15 & 3,41 & 0,24 & \multirow{3}{*}{0,876} & \multirow{3}{*}{0,351} \\
\hline & Hayır & 151 & 3,33 & 0,32 & & \\
\hline & Total & 166 & 3,34 & 0,31 & & \\
\hline \multirow[t]{3}{*}{ Özyeterlilik } & Evet & 15 & 3,18 & 0,54 & \multirow{3}{*}{0,530} & \multirow{3}{*}{0,468} \\
\hline & Hayır & 151 & 3,29 & 0,56 & & \\
\hline & Total & 166 & 3,28 & 0,56 & & \\
\hline \multirow[t]{3}{*}{ Motivasyon } & Evet & 15 & 3,46 & 0,28 & \multirow{3}{*}{1,154} & \multirow{3}{*}{0,284} \\
\hline & Hayır & 151 & 3,33 & 0,47 & & \\
\hline & Total & 166 & 3,34 & 0,46 & & \\
\hline \multirow[t]{3}{*}{ İlgi } & Evet & 15 & 3,71 & 0,36 & \multirow{3}{*}{3,721} & \multirow{3}{*}{$0,045^{*}$} \\
\hline & Hayır & 151 & 3,45 & 0,51 & & \\
\hline & Total & 166 & 3,47 & 0,50 & & \\
\hline \multirow[t]{3}{*}{ Mesleki Alana Yönelik Gereklilik } & Evet & 15 & 3,11 & 0,39 & \multirow{3}{*}{0,070} & \multirow{3}{*}{0,792} \\
\hline & Hayır & 151 & 3,15 & 0,50 & & \\
\hline & Total & 166 & 3,15 & 0,49 & & \\
\hline \multirow[t]{3}{*}{ Beklenti } & Evet & 15 & 3,35 & 0,43 & \multirow{3}{*}{3,034} & \multirow{3}{*}{0,083} \\
\hline & Hayır & 151 & 3,14 & 0,44 & & \\
\hline & Total & 166 & 3,16 & 0,44 & & \\
\hline \multirow[t]{3}{*}{ Kayg1 } & Evet & 15 & 3,52 & 0,62 & \multirow{3}{*}{ o,ooo } & \multirow{3}{*}{0,992} \\
\hline & Hayır & 151 & 3,52 & 0,69 & & \\
\hline & Total & 166 & 3,52 & 0,69 & & \\
\hline \multirow[t]{3}{*}{ Gereklilik ve Önem } & Evet & 15 & 4,27 & 0,65 & \multirow{3}{*}{1,293} & \multirow{3}{*}{0,257} \\
\hline & Hayır & 151 & 3,95 & 1,04 & & \\
\hline & Total & 166 & 3,98 & 1,02 & & \\
\hline
\end{tabular}

${ }^{*} \mathrm{p}<0,05$

Bağımsız gruplarda t testi sonuçlarına göre Arapça dersine karşı tutum ölçeği alt boyutlarından ilgi alt boyutu Kur’an-ı Kerim hafizlığı yapma durumuna göre anlamlı düzeyde farklılık göstermektedir $(\mathrm{p}<0,05)$. Kur’an-ı Kerim hafizlığı yapanların ilgi düzeyi yapmayanlardan anlamlı derecede daha yüksektir.

\section{Arapça dersine karşı tutum ölçeğinin Arapça dersine çalışmak için ayrılan süreye göre değişimi}

Arapça dersine karşı tutum ölçeğinin Kuran-ı Kerim Hafızlığı yapma durumuna göre ortalamaları ve bu ortalamalar arasındaki farkın anlamlı olup olmadığının tespiti için yapılan tek yönlü varyans analizi sonuçları verilmiştir. 
Tablo-12: Arapça Dersine Çalışmak İçin Ayrılan Süreye Göre Değişim

\begin{tabular}{|c|c|c|c|c|c|c|}
\hline & & $\mathrm{n}$ & Ortalama & Std. Sapma & $\mathrm{F}$ & $\mathrm{p}$ \\
\hline \multirow[t]{8}{*}{ Toplam } & Hiç & 7 & 3,17 & 0,34 & \multirow{8}{*}{0,892} & \multirow{8}{*}{0,503} \\
\hline & $<1$ saat & 10 & 3,42 & 0,34 & & \\
\hline & 1-2 saat & 27 & 3,38 & 0,19 & & \\
\hline & 3-4 saat & 34 & 3,34 & 0,30 & & \\
\hline & 5-6 saat & 27 & 3,26 & 0,50 & & \\
\hline & 7-8 saat & 19 & 3,35 & 0,24 & & \\
\hline & 8 saatten fazla & 42 & 3,36 & 0,22 & & \\
\hline & Total & 166 & 3,34 & 0,31 & & \\
\hline \multirow[t]{8}{*}{ Özyeterlilik } & Hiç & 7 & 3,49 & 0,54 & \multirow{8}{*}{2,198} & \multirow{8}{*}{$0,046^{*}$} \\
\hline & $<1$ saat & 10 & 3,51 & 0,55 & & \\
\hline & 1-2 saat & 27 & 3,48 & 0,33 & & \\
\hline & 3-4 saat & 34 & 3,35 & 0,65 & & \\
\hline & 5-6 saat & 27 & 3,22 & 0,68 & & \\
\hline & 7-8 saat & 19 & 3,05 & 0,50 & & \\
\hline & 8 saatten fazla & 42 & 3,15 & 0,49 & & \\
\hline & Total & 166 & 3,28 & 0,56 & & \\
\hline \multirow[t]{8}{*}{ Motivasyon } & Hiç & 7 & 2,92 & 0,43 & \multirow{8}{*}{3,718} & \multirow{8}{*}{$0,002^{*}$} \\
\hline & $<1$ saat & 10 & 3,20 & 0,47 & & \\
\hline & 1-2 saat & 27 & 3,33 & 0,27 & & \\
\hline & 3-4 saat & 34 & 3,31 & 0,43 & & \\
\hline & 5-6 saat & 27 & 3,18 & 0,62 & & \\
\hline & 7-8 saat & 19 & 3,40 & 0,30 & & \\
\hline & 8 saatten fazla & 42 & 3,56 & 0,43 & & \\
\hline & Total & 166 & 3,34 & 0,46 & & \\
\hline \multirow[t]{8}{*}{ İlgi } & Hiç & 7 & 2,97 & 0,75 & \multirow{8}{*}{3,591} & \multirow{8}{*}{$0,002^{*}$} \\
\hline & $<1$ saat & 10 & 3,40 & 0,72 & & \\
\hline & 1-2 saat & 27 & 3,31 & 0,35 & & \\
\hline & 3-4 saat & 34 & 3,45 & 0,40 & & \\
\hline & 5-6 saat & 27 & 3,40 & 0,63 & & \\
\hline & 7-8 saat & 19 & 3,67 & 0,40 & & \\
\hline & 8 saatten fazla & 42 & 3,66 & 0,41 & & \\
\hline & Total & 166 & 3,47 & 0,50 & & \\
\hline \multirow{5}{*}{$\begin{array}{l}\text { Mesleki Alana } \\
\text { Yönelik Gereklilik }\end{array}$} & Hiç & 7 & 3,23 & 0,50 & \multirow{5}{*}{1,043} & \multirow{5}{*}{0,399} \\
\hline & $<1$ saat & 10 & 3,36 & 0,54 & & \\
\hline & 1-2 saat & 27 & 3,27 & 0,50 & & \\
\hline & 3-4 saat & 34 & 3,13 & 0,39 & & \\
\hline & 5-6 saat & 27 & 3,06 & 0,60 & & \\
\hline
\end{tabular}




\begin{tabular}{|c|c|c|c|c|c|c|}
\hline & 7-8 saat & 19 & 3,19 & 0,49 & & \\
\hline & 8 saatten fazla & 42 & 3,06 & 0,46 & & \\
\hline & Total & 166 & 3,15 & 0,49 & & \\
\hline Beklenti & Hiç & 7 & 3,24 & 0,67 & & \\
\hline & $<1$ saat & 10 & 3,39 & 0,52 & & \\
\hline & 1-2 saat & 27 & 3,17 & 0,28 & & \\
\hline & 3-4 saat & 34 & 3,20 & 0,36 & 0803 & 0.560 \\
\hline & 5-6 saat & 27 & 3,12 & 0,58 & 0,003 & 0,509 \\
\hline & 7-8 saat & 19 & 3,19 & 0,36 & & \\
\hline & 8 saatten fazla & 42 & 3,08 & 0,46 & & \\
\hline & Total & 166 & 3,16 & 0,44 & & \\
\hline Kayg1 & Hiç & 7 & 3,26 & 0,75 & & \\
\hline & $<1$ saat & 10 & 3,72 & 0,47 & & \\
\hline & 1-2 saat & 27 & 3,71 & 0,47 & & \\
\hline & 3-4 saat & 34 & 3,45 & 0,75 & 1142 & O 240 \\
\hline & 5-6 saat & 27 & 3,56 & 0,75 & 1,143 & 0,340 \\
\hline & 7-8 saat & 19 & 3,64 & 0,51 & & \\
\hline & 8 saatten fazla & 42 & 3,38 & 0,79 & & \\
\hline & Total & 166 & 3,52 & 0,69 & & \\
\hline Gereklilik ve & Hiç & 7 & 2,86 & 1,49 & & \\
\hline & $<1$ saat & 10 & 3,90 & 1,31 & & \\
\hline & 1-2 saat & 27 & 3,67 & 0,94 & & \\
\hline & 3-4 saat & 34 & 4,04 & 0,94 & 2,779 & $0.013^{*}$ \\
\hline & 5-6 saat & 27 & 3,96 & 1,05 & $2, / 19$ & \\
\hline & 7-8 saat & 19 & 4,11 & 0,91 & & \\
\hline & 8 saatten fazla & 42 & 4,30 & 0,86 & & \\
\hline & Total & 166 & 3,98 & 1,02 & & \\
\hline
\end{tabular}

${ }^{*} \mathrm{p}<0,05$

Tek yönlü varyans analizi sonuçlarına göre; Arapça dersine yönelik tutum ölçeği alt boyutlarından öz yeterlilik, motivasyon, ilgi ve gereklilik ve önem alt boyutu Arapça dersine çalışmak için ayrılan süreye göre anlamlı düzeyde farklılı göstermektedir $(\mathrm{p}<0,05)$. Anlamlı farklılık gösteren alt boyutlar için farklılığın hangi gruptan kaynaklandığını tespit etmek için yapılan TUKEY testi sonuçlarına göre;

Öz yeterlilik alt boyutu için; 1 saatten az ve 1-2 saat vakit ayıranların öz yeterlilik düzeyleri 7-8 saat ayıranlardan anlamlı düzeyde daha yüksektir. Ek olarak 1-2 saat vakit ayıranların öz yeterlilik düzeyi 8 saatten fazla zaman ayıranlardan anlamlı derecede daha yüksektir.

Motivasyon alt boyutu için; Arapça dersine çalışmak için 8 saatten fazla vakit ayıranların motivasyon düzeyi hiç vakit ayırmayanlar, 1 saatten az vakit ayıranlar ile 1-2 saat, 3-4 saat ve 5-6 saat vakit ayıranlardan anlamlı derecede daha yüksektir. 
İlgi alt boyutu için; Arapça dersine 3-4 saat ve 5-6 saat ayıranların ilgi düzeyi hiç vakit ayırmayanlardan, 7-8 saat vakit ayıranların ilgi düzeyi hiç vakit ayırmayanlar ve 1-2 saat ayıranlardan, 8 saatten fazla vakit ayıranların ilgi düzeyi hiç vakit ayırmayanlar, 1-2 saat ve 5-6 saat ayıranlardan anlamlı derecede daha yüksektir.

Gereklilik ve önem alt boyutu için; Arapça dersine çalışmak için 1 saatten az, 3-4 saat, 5-6 saat ve 8 saatten fazla vakit ayıranların gereklilik ve önem düzeyleri hiç vakit ayırmayanlardan anlamlı derecede daha yüksektir.

\section{Tartışma ve sonuç}

BUÜ İlahiyat Fakültesi Arapça hazırlık sınıfında öğrenim gören öğrencilerin Arapça öğrenimlerine yönelik tutum düzeyleri özyeterlilik, motivasyon, ilgi, mesleki alana yönelik gereklilik, beklenti, kaygı, gereklilik ve önem alt boyutlarıyla incelenmiştir.

Bağımsız değişkenler üzerinden yapılan inceleme neticesinde elde edilen sonuçlara göre;

1) Örgün öğretim ve ikinci öğretim öğrencilerinin Arapça dersine karşı genel tutum düzeyi ve alt boyutları düzeyleri aynı seviyededir. Ulaşılan bu sonuç Özcan ve Yapıcı tarafından yapılan araştırma sonucuyla uyum göstermektedir (Özcan \& Yapıcı, 2016, s. 136).

2) Kadınların Arapça dersine karşı tutum ölçeği toplamı ile öz yeterlilik, kaygı ve gereklilik ve önem alt boyutları erkeklerden anlamlı derecede daha yüksektir. Arpaçukuru ve Üzümcü’nün (Arpaçukuru \& Üzümcü, 2020, s. 883) çalışması cinsiyet farkına dayalı bir tutum farklı olmadığını ortaya koyarken çalışmamızda elde ettiğimiz sonuçlar Kömürcü ve Aydoslu tarafından ayrı ayrı yapılan çalışmaların sonuçlarıyla uyum göstermektedir. Sözü edilen çalışmalar duyuşsal ve davranışsal boyutta kadın öğrencilerle erkek öğrenciler arasında anlamlı bir fark olduğunu ortaya koymuştur (Aydoslu, 2005, s. 69; Kömürcü, 2015, s. 136). Özcan ve Yapıcı'nın araştırma sonuçları da kadın öğrencilerin tutum puanının erkek öğrencilerinkinden anlamlı derecede yüksek olduğunu göstermektedir (Özcan \& Yapıcı, 2016, s. 135)

3) Yaş gruplarına göre ilgi ve kaygı alt boyutları anlamlı düzeyde farklılık göstermektedir. $25^{+}$yaş grubunun ilgi boyutu 18-24 yaş grubundan anlamlı düzeyde daha yüksek iken, 18-24 yaş grubunun kaygı düzeyi 25+ yaş grubundan anlamlı derecede daha yüksektir. Yaş grupları açısından değerlendirmede bulunan bir çalışma tespit edemediğimiz için tartışma imkânımız olmamıştır. Ancak 25+ yaş grubundaki öğrencilerin kendilerinden yaşça küçük gruptaki öğrencilere göre ilgi boyutunun yüksek düzeyde, kaygı boyutunun ise daha düşük düzeyde olması bu öğrencilerin daha önceden aldıkları eğitimden ve edindikleri hayat tecrübesinden kaynaklandığı yorumu yapılabilir.

4) Daha önce mezun olunan okul türüne göre ilgi ve kaygı alt boyutları anlamlı düzeyde farklılık göstermektedir. Hazırlık sınıfı öğrencileri arasında daha önce başka bir lisans bölümünden mezun olanların ilgi düzeyi imam hatip lisesi, diğer lise ve ilahiyat ön lisans mezunlarından anlamlı derecede daha büyüktür. Bunun yanında ilahiyat ön lisans mezunlarının ilgi düzeyi, imam hatip lisesi ve diğer lise mezunlarından anlamlı derecede daha büyüktür. Kaygı alt boyutu için imam hatip lisesi ve diğer lise mezunlarının kaygı düzeyi diğer gruplardan anlamlı derecede daha yüksektir. Mezun olunan lise türü açısından bakıldığında gereklilik ve önem alt boyutu açısından ise diğer lise mezunları grubunun imam hatip lisesi mezunları grubuna göre anlamlı derecede yüksek olduğu görülmekte iken genel tutum ölçeği toplamı açısından ulaşılan sonuçlar imam hatip lisesi mezunları ile diğer lise mezunları arasında anlamlı 
bir farkın bulunmadığını göstermektedir. Genel tutum açısından elde edilen bu sonucun Kömürcü'nün (Kömürcü, 2015, s. 137) ve Özcan ve Yapıcı'nın (Özcan \& Yapıcı, 2016, s. 137) çalışmalarıyla uyumlu olduğu görülmektedir.

5) Türk ve yabancı öğrencilerin Arapça dersine karşı tutum ölçeği toplamı ile alt boyutları aynı düzeydedir. Öğrencilerin uyrukları açısından değerlendirmede bulunan bir çalışma tespit edemediğimiz için tartışma imkânımız olmamıştır.

6) Annesi farklı eğitim seviyesine sahip kişilerin Arapça dersine karşı tutum düzeyleri aynı seviyede iken baba eğitim durumuna göre kaygı alt boyutu anlamlı düzeyde farklılık göstermektedir. Babası okuma yazma bilmeyen, ilkokul mezunu olan ve ön lisans mezunu olanların kaygı düzeyi babası ortaokul/lise, üniversite ve yüksek lisans/doktora mezunu olanların kaygı düzeyinden anlamlı derecede daha yüksektir. Ebeveyn eğitim düzeyleri açısından değerlendirmede bulunan bir çalışma tespit edemediğimiz için tartışma imkânımız olmamıştır. Baba eğitim düzeyinin öğrencilerin kaygı düzeyleri üzerinde etkili olduğu sonucu dikkat çekicidir.

7) Arapça özel ders alan ve almayanların Arapça dersine karşı tutum ölçeği düzeyleri aynı seviyededir. Daha önce Arapça özel ders alınıp alınmamış olması açısından değerlendirmede bulunan bir çalışma tespit edemediğimiz için tartışma imkânımız olmamıştır.

8) İlahiyat fakültesine isteyerek gelenlerin, Kur'an-ı Kerim hafızlı̆̆ı yapanların ilgi düzeyi yapmayanlardan anlamlı derecede daha yüksektir. Bu yönlerden değerlendirmede bulunan bir çalışma tespit edemediğimiz için tartışma imkânımız olmamıştır. Ancak fakülteye istekli gelmek ve hafızlık yapmış olmanın öğrencilerin ilgi düzeylerinin diğer öğrencilere nazaran yüksek olması Arap diline öğrenme konusunda bu öğrencilerde hazır bulunuşluk meydana getirmiş olması ile açıklanabilir.

9) Arapça dersine çalışmak için ayrılan süreye göre öz yeterlilik, motivasyon, ilgi ve gereklilik ve önem alt boyutu anlaml düzeyde farklılık göstermektedir. Arapça dersine çalışmak için ayrılan süre açısından bakıldığında bir haftada 7-8 saat ve 8 saatten daha fazla vakit ayıran öğrencilerin toplama oranının \%36,7 olduğu görülmektedir. Bu sonuca göre öğrencilerin büyük çoğunluğunun Arapça dersine çalışmak için yeterince vakit ayırmadıklarını söylemek mümkündür. Kömürcü’nün (Kömürcü, 2015, s. 137) ve Arpaçukuru ile Üzümcü’nün (Arpaçukuru \& Üzümcü, 2020, s. 880) ulaştıkları sonuçlarla uyum gösteren bu sonuç, üzerinde ayrıca düşünülmeye, değerlendirilmeye ve çeşitli çalışmalar yapmaya değer görülmektedir.

\section{Öneriler}

- Arapça hazırlık sınıfında okuyan öğrencilerin Arap dilini öğrenmenin önemi, gerekliliği konusunda bilgilendirilmeleri, bu bilgilendirmenin öğrencinin tutumunu olumlu geliştirecek ve motivasyonu arttıracak tarzda ve yıl içine yayılmış olarak gerçekleştirilmesi sağlanabilir.

- Ders materyali olarak kullanılan kitap setinden, sınıf içindeki teknik ekipmana, öğretim elemanından, sınıf düzenine kadar öğrencinin tutumuna etki edebilecek faktörler üzerinde çalışmalar yürütülebilir.

- Öğretim elemanlarının genel olarak dil öğretim teknikleri ve özellikle de Arapça öğretim teknikleri bakımından donanımlı olmalarını, yenilikleri takip etmelerini ve bunları derslerinde 
uygulamalarını sağlayacak çeşitli imkânların tespit edilmesi ve bunlardan yararlanılması yerinde olacaktır.

- Öğrencilerin haftalık ders çalışma saatlerinin arttırılmasına ya da ders dışında Arapça ile olan irtibatlarının güçlendirilmesine yönelik neler yapılabileceği konusunda stratejiler geliştirilebilir.

- Öğrencilerin tutumlarını etkileyen faktörler tespit edilip bunlar içinde değiştirilmesi mümkün olanlarla ilgili iyileştirmeler yönünde stratejiler geliştirilebilir.

\section{Kaynakça}

Anderson, L. W. (1988). Attitudes and Their Measurement. İçinde J. P. Keeves (Ed.), Educational Research, Methodology and Measurement: An International Handbook. Pergamon.

Arpacı, M. (2014). İlköğretim Din Kültürü ve Ahlak Bilgisi Öğretmenliği Bölümü Öğrencilerinin Öğretmenlik Meslek Bilgisi Derslerine Yönelik Tutumlarının İncelenmesi. Değerler Eğitimi Dergisi, 12(27), 75-98.

Arpaçukuru, O., \& Üzümcü, M. (2020). İlahiyat Fakültesi Hazırlık Sınıfı Öğrencilerinin Arapça Dersine İlişkin Tutumları (Tekirdağ Namık Kemal Üniversitesi Örneği). 6(2), 853-886.

Aydoslu, U. (2005). Öğretmen Adaylarının Yabancı Dil Olarak İngilizce Dersine İlişkin Tutumlarının İncelenmesi (B.E.F. Örneği). Süleyman Demirel Üniversitesi.

Civelek, Y. (1998). Türkiye’de Arapça Öğretimine Dair Bazı Teklifler -Riyad Arap Dil Enstitüsü Örneği-. Yüzüncü Yıl Üniversitesi İlahiyat Fakültesi Dergisi, 2, 225-283.

Dündar, A. İ. (2020). İlahiyat Fakültesi Arapça Hazırlık Sınıfı Öğrencilerinin Arapça Dersine İlişkin Tutumlarının İncelenmesi (Kocaeli Üniversitesi, İlahiyat Fakültesi Örneği). Kocaeli İlahiyat Dergisi, 4(1), 85-100.

Ekmekçi, F. Ö. (1983). Yabancı Dil Eğitimi Kavram ve Kapsamı. Türk Dili (Dil Öğretimi Özel Sayısı), 379-380, 107-115.

Genç, M. F. (2013). Öğretmenler Gözüyle İlköğretim Din Kültürü ve Ahlak Bilgisi Dersinde Değerler Eğitimi (1. bs). Etüt Yayınevi.

Kline, P. (1994). An Easy Guide to Factor Analysis. Routledge.

Kocaman, A. (1983). Yabancı Dil Öğretiminde Yeni Yönelimler. Türk Dili (Dil Öğretimi Özel Sayısı), 379380, 116-122.

Kömürcü, A. (2015). İlahiyat Fakültesi Hazırlı Sınıfı Öğrencilerinin Arapça Dersine İlişkin Tutumlarının İncelenmesi (D.Ü.İ.F. Örneği). Celal Bayar Üniversitesi Sosyal Bilimler Dergisi, 13(3), 119-140.

Özcan, Y., \& Geçioğlu, A. R. (2021). İlahiyat Fakültesi Hazırlık Sınıfı Öğrencilerinin Yabancı Dil Öğrenme Gayretlerinin İncelenmesi (Ç.Ü. İlahiyat Fakültesi Örneği). Çukurova Üniversitesi İlahiyat Fakültesi Dergisi, 21(1), 386-409.

Özcan, Y., \& Yapıcı, A.. (2016). İlahiyat Fakültesi Öğrencilerinin Arapça Dersine İlişkin Tutumlarının İncelenmesi (Ç.Ü. İlahiyat Fakültesi Örneği). Çukurova Üniversitesi İlahiyat Fakültesi Dergisi, 16(2), 113-142.

Pan, V., \& Akay, C. (2015). Eğitim Fakültesinde Yabancı Dil Dersi Alan Öğrencilerin Yabancı Dil Dersine Yönelik Tutumlarının ve Sınıf Kaygılarının İncelenmesi. Elektronik Sosyal Bilimler Dergisi, 14. https://doi.org/10.17755/esosder.14574

Peers, I. (1996). Statistical Analysis for Education and Psychology. Falmer.

Soysaldı, M. (2010). Türkiye'deki İlahiyat Fakültelerinde Arapça Öğretiminde Karşılaşllan Problemler ve Çözüm Yolları. EKEV Akademi Dergisi, 14(45), 247-279. 
Soyupek, H. (2004). İkinci Meşrutiyet’ten Günümüze Türkiye’de Arapça Öğretimi. Süleyman Demirel Üniversitesi.

Tavşancıl, E. (2005). Tutumların Ölçülmesi ve SPSS İle Veri Analizi. Nobel Yayıncılık.

Tezbaşaran, A. A. (2008). Likert Tipi Ölçek Hazırlama Kılavuzu (e-kitap) (3. bs). Türk Psikologlar Derneği. http://www.academia.edu/1288035/Likert_Tipi_Ölçek_Hazırlama_Kılavuzu

Turan, İ., Şimşek, Ü., \& Aslan, H. (2015). Eğitim Araştırmalarında Likert Ölçeği ve Likert-Tipi Soruların Kullanımı ve Analizi. Sakarya Üniversitesi Ĕgitim Fakültesi Dergisi, 30, 186-203.

Uçar, R. (2015). İlahiyat Fakültesi Öğrencilerinin Arapça Dersine Karşı Tutumları (İnönü Üniversitesi İlahiyat Fakültesi Örneği). Marife Dini Araştırmalar Dergisi, 15(2), 371-394.

Üçok, N. (2004). Genel Dilbilim: Lengüistik. İstanbul : Multilingual. 